\title{
The impact of European landscape transitions on the provision of landscape services: an explorative study using six cases of rural land change
}

\author{
Theo Van der Sluis $(\mathbb{D} \cdot$ Bas Pedroli $(\mathbb{D} \cdot$ Pia Frederiksen • Søren B. P. Kristensen • \\ Anne Gravsholt Busck • Vangelis Pavlis • Georgia Lavinia Cosor
}

Received: 19 May 2018/Accepted: 3 December 2018/Published online: 13 December 2018

(C) The Author(s) 2018

\begin{abstract}
Context The reasons for recent landscape change in the European countryside are complex and poorly substantiated. Identification of drivers of landscape transition and assessment of the effects on the provision of landscape services are subject of recent debate.
\end{abstract}

Objectives Aims of the paper are to explore what implications rural landscape transitions (as identified by land use and land cover changes) have for the

Electronic supplementary material The online version of this article (https://doi.org/10.1007/s10980-018-0765-2) contains supplementary material, which is available to authorized users.

T. Van der Sluis $(\bowtie) \cdot$ B. Pedroli

Wageningen Environmental Research, P.O. Box 47,

6700 AA Wageningen, The Netherlands

e-mail: Theo.vanderSluis@wur.nl

\section{P. Frederiksen}

Department of Environmental Science, Aarhus

University, Frederiksborgvej 399, 4000 Roskilde,

Denmark

S. B. P. Kristensen - A. G. Busck

Department of Geosciences and Natural Resource

Management, University of Copenhagen, Oester

Voldgade 10, 2100 Copenhagen, Denmark

V. Pavlis

Department of Geography, University of the Aegean,

University Hill, 81100 Mitiline, Lesvos, Greece provision of landscape services, and whether these changes can be related to specific drivers of change.

Methods The paper records gross landscape change on the basis of land use and land cover changes in six case study areas in five countries, and assesses the impacts on the provision of landscape services in the past 25 years.

Results In the past decades the observed land use and land cover changes in the case studies are relatively small, with a dominance of urbanisation and afforestation processes. However, the impacts of these changes are clearly reflected in a change in landscape services. Conclusions Although the landscape transitions do affect the services, spatial data alone is insufficient to

\footnotetext{
G. L. Cosor

Department of Systems Ecology and Sustainability, University of Bucharest, Spl. Independentei 91-95, Bucharest, Romania
} 
assess cause-effect relationships of landscape transitions, landscape structure and pattern. Circumstantial evidence points to substantial effects of EU and national policies on landscape services through landscape transition. These-often unintentional-effects can substantially affect biodiversity, cultural identity and landscape character. More research is needed on the exact cause-effect relationships between policies and landscape service provision.

Keywords Landscape change $\cdot$ LULC $\cdot$ Cultural services · Ecosystem services · Case studies · Landscape governance $\cdot$ Multifunctionality $\cdot$ MRT

\section{Introduction}

The character of Europe's countryside is changing (Rounsevell et al. 2012; Primdahl 2014; Van Vliet et al. 2015) as a result of urbanisation, changing demographic patterns, climate change, changing societal demands and new economic functions (EEA 2015). This is reflected in landscape changes, the most prominent of which are an increase in artificial surfaces and forested areas and a decrease in arable land and pastures. From 2000 to 2006 the net annual change across 36 European countries was $1.3 \%$ (EEA 2010). Fuchs et al. (2015) compared different global data sets and calculated the area of land affected by changes during the period 1900-2010 and found a gross change of $56 \%$ of the total area of all EU27 states (plus Switzerland), i.e. on average a change of $0.5 \%$ per annum. Moreover, projected land demands are much higher than what is available, e.g. to satisfy all land use needs in Denmark has been estimated to require up to $140 \%$ of the territory by 2050 (Arler et al. 2017).

The diverse impacts of landscape change have been described by many authors, such as changes in landscape identity and landscape quality (Stobbelaar and Pedroli 2011; Antrop et al. 2013), biodiversity and connectivity (Rüter et al. 2014; EEA 2015; Cormont et al. 2016). The impacts manifest themselves in a changed composition of the associated ecosystem services at landscape level (Huntsinger and Oviedo 2014). Landscape services have been coined as 'goods and services provided by a landscape to satisfy human needs, directly and indirectly' (Termorshuizen and
Opdam 2009). Landscape services are founded in the Ecosystem Services concept, and these include provisioning, regulating, cultural, and supporting services (MA 2005). Although the exact difference between landscape services and ecosystem services can be debated (see e.g. the Special Issue on ecosystem services in cultural landscapes compiled by Plieninger et al. 2014), we consider the landscape services concept as more appropriate for landscape studies due to their explicit spatial connotation and more obvious comprehension in terms of landscape patterns and societal functions (Termorshuizen and Opdam 2009; Bastian et al. 2014; Bürgi et al. 2015; Opdam et al. 2015). Where ecosystem services are criticised for being dominated by market based values, and being of an exploitative nature (Albert et al. 2014b), Plieninger argues that landscape services relate more to cultural services and can be used to complement the biophysical and market based quantification of ecosystem services (Plieninger et al. 2015). Main landscape services include provisioning services (crops, feeds, livestock and industrial production), regulatory services (water retention, pollination, carbon storage), cultural services (tourism, cultural heritage, housing, inspiration, hobby farming) (Hornigold et al. 2016) and supporting services \& biodiversity (wildlife habitat) (Brandt and Vejre 2003). The concept of landscape services was developed further by linking ecosystem services to specific services that are most relevant for rural residents (Vallés-Planells et al. 2014). In this paper we will further use the concept of landscape services in the analytical framework for the assessment of landscapes transitions and their relevance to society.

A better understanding of the dominant landscape transition processes and their impact on the provision of landscape services may be important to develop better policies and regulations to guide in landscape development, which can lead to a more optimal allocation of land resources (Vallés-Planells et al. 2014).

However, as Stürck and Verburg (2016) indicate, the indicators and scale which are used to assess landscape services substantially affect the outcome of the assessment, and they recommend that land use policy be adapted to location specific impacts of land use/land cover (LULC) change on landscape services. Therefore this paper presents six case studies located in five European countries, which illustrate a variety of 
local processes of change across the European countryside. These cases represent primarily those gradual changes that are related to rural land use, rather than impacts of infrastructural works, industrial developments or the energy transition. The study reported here could be called a large-scale analysis (Bürgi et al. 2017), in which main trends and processes over large areas are assessed. The goal of the paper is to explore what implications rural landscape transitions (as identified by land use and land cover changes) have for the provision of landscape services, and whether these changes can be related to specific drivers of change. This leads to the following research questions:

- What are the landscape transitions which have occurred in the European countryside over the past three decades in the six cases studied?

- What are the associated changes in landscape services provision?

- What can be concluded about the transformations taking place in the European countryside?

\section{Landscape transitions and drivers of change}

Going beyond the directly observable landscape change in its temporal and spatial dimensions (Tress and Tress 2001), we define landscape transition as a long term fundamental change in Land Use and Land Cover which represents both the type of services provided, and the physical properties of the landscape. Transitions can take place as land cover change (e.g. from forest to urban area, or from farmland to forest), but also as land use change (e.g. from permanent grassland to improved grassland). Such landscape transitions can be considered the result of a changing balance between societal consumption, conservation and production (Holmes 2008; Pinto-Correia et al. 2016) and of changing modes of occupancy (use of rural space) (Holmes 2008, p. 212) of land owners and managers, where the socio-economic context defines the outcome of the transition process (EEA 2017). Various approaches have been reported to explain landscape transitions, ranging from describing parallel phenomena to cause-effect relationships, from linear to multi-sectoral explanations.

In many cases, straightforward sectoral approaches have successfully been used so far, such as for forests (Oduro et al. 2015) or farmland (Van Doorn and Bakker 2007). Paying tribute to the complexity of the land system, Wilson (2007) proposes a multidisciplinary approach to explain agricultural landscape transitions. Realising that many factors contribute to rural landscape dynamics besides agricultural production, Holmes (2008) introduces the concept of Multifunctional Rural Transition (MRT) and uses this framework to explain rural changes under the influence of certain economic conditions, landscape governance and environmental change, for parts of Australia (Holmes 2012). Holmes' framework has also been applied to study change processes occurring in Europe (Carvalho-Ribeiro et al. 2013; Pinto-Correia et al. 2016), where conditions differ considerably from region to region, especially regarding the available land resources and spatial claims on land. Holmes' framework balances production, consumption and protection: from a 'mono-functional' landscape (Fig. 1, top of the triangle, e.g. industrial farming) towards a multifunctional landscape (centre, e.g. mixed family farming); from production oriented (top) towards provision of a wider array of landscape services, such as housing, recreation (lower left), habitat function (lower right), etc. (Fig. 1). The same principle applies for changes in forest management, which balances between production, conservation and amenity values (Forest Europe 2015).

Holmes' framework is of particular relevance for a better understanding of regional processes, it transcends the farm or plot level and incorporates other aspects of drivers of landscape change such as demography and socio-economic changes, which makes the framework useful to explain landscape transitions. Interestingly, there remains a gap-or at least a time lag-between the gradual but fundamental changes in landscape functions, and the associated changes at field level. The former (landscape transitions) and the latter (landscape changes) are much connected, but are not identical: a shift towards higher production and intensification will most likely have impact on landscape pattern at field level (but not always immediately), e.g. the land manager will sooner or later adjust the pattern of his fields as required for access by larger machines. Landscape persistence could easily be misinterpreted as stable land use (e.g. in terraced landscapes, Van der Sluis et al. 2014a, b; cfr. Bürgi et al. 2017). This paper adopts the landscape services approach described above to explain this subtle differentiation in the cases 
Fig. 1 Use of rural space of land managers, after Holmes (2008) and Pinto-Correia et al. (2016)

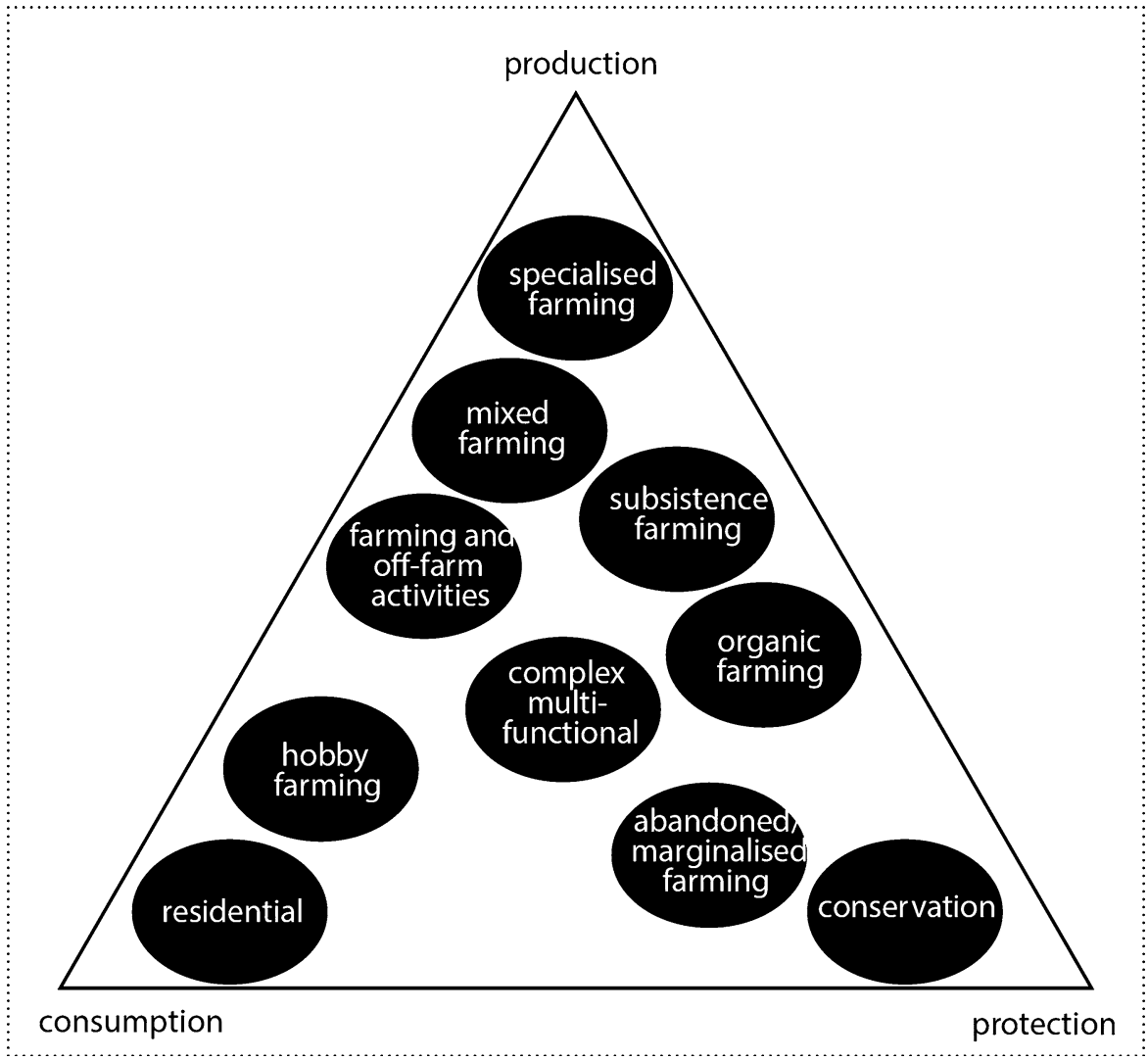

studied, and relates the landscape transitions to the change in services.

Explaining the complex landscape transitions addressed above also requires better identification and understanding of the drivers of change. Specific direct and indirect driving forces can lead to landscape transitions, while other forces result in landscape persistence and stability (Klijn 2004). Understanding these processes provides opportunities to develop proper policy response. Bürgi et al. (2017) identified as drivers for six case studies: access and infrastructure, labour market, calamities (Soviet occupation), legal homogenisation (EU) and technological innovations (Bürgi et al. 2017), referring to a time frame from 1850 to 2014. In this paper we focus on the landscape transitions over the last 25 years, a period of special interest for assessing the impact of European policies on the landscape.

\section{Data and methods}

A case-study approach was adopted to assess the landscape transitions and their impact on landscape service provision. An approximation of landscape transitions at EU scale can be derived from CORINE data bases (Feranec et al. 2016). However, land cover change does not necessarily reflect all changes in land use intensity, and the changing landscape functions may affect the provision of landscape services in various ways when land cover changes. As an example, afforestation may lead to decreased surface run-off and improved infiltration, resulting in reduced flood risk or climate resilience. Zooming in on the specific land use change processes taking place in selected landscapes in Europe provides a level of detail lacking in large-scale European landscape assessments because of the scale of observation and the time lag in land cover change following gradual land use transitions (Fuchs et al. 2016). Studying location specific impacts of land use changes on landscape services might be crucial to detect how land 
managers may be implicated and what response this may solicit from landscape governance (Stürck and Verburg 2016). Therefore, six case study areas were selected, in different regions and landscapes across Europe: Roskilde (Denmark), Heerde (The Netherlands), Portofino (Italy), Lesvos (Greece), and Răteşti and Stăncuţa (Romania) (Fig. 2). The case study areas provide a kaleidoscope of landscape transitions in Europe and exemplify the change processes observed. Previous research that had been conducted ensured background knowledge on land use dynamics in these areas (Van der Sluis et al. 2014b). The smallest area, Portofino, measures $18 \mathrm{~km}^{2}$ whereas the largest area, Stăncuţa (RO), measures more than $257 \mathrm{~km}^{2}$. They form a cross-section of European physical and cultural landscapes and are situated in Atlantic, Mediterranean, Continental and Pannonian zones (Table 1). The two Mediterranean case studies are both predominantly rural areas. The dominant land use on Lesvos (GR) is olive growing which dates back for centuries. Small-scale tourism, dispersed over the island, is gradually increasing. Portofino (IT) was previously intensively used for farm and forest products and then turned into a protected area. Land is mostly state owned, and the dominant land cover is macchia (maquis) and olive yards. Dominant land use in the Northern European case study, Roskilde (DK) is arable farming. There is a strong urban pressure on this area from nearby Copenhagen, which leads to conversion of land and farms for non-agricultural purposes (Kristensen et al. 2013). Land use is also mostly arable in the two case studies located in Eastern Europe, Stăncuţa and Răteşti (RO). In Romania the land has been state owned for almost half a century, but since 1989 at the dissolution of the USSR and fall of the communist government land ownership has mostly been reverted to smallholders again. The impact of these major changes still affects current processes of landscape change. In the central Atlantic case study, Heerde (NL), land use is mostly dairy farming, land ownership lies in most cases with smallholders (Hauser et al. 2016). The area experiences urban pressure from nearby cities.

\section{Data acquisition and processing}

A spatially explicit temporal analysis was carried out of landscape transitions in the case study areas, based on a comparison of land use/land cover maps over a longer period (at least 10 years). Time series for at least two periods were used. The first period for comparison lies between 1972 (establishment of the European Economic Community) and 1992, since European Union (EU) legislation may be considered one of the key policy drivers of landscape processes in Europe in recent decades emphasising production and
Fig. 2 Location of the six case studies in five countries

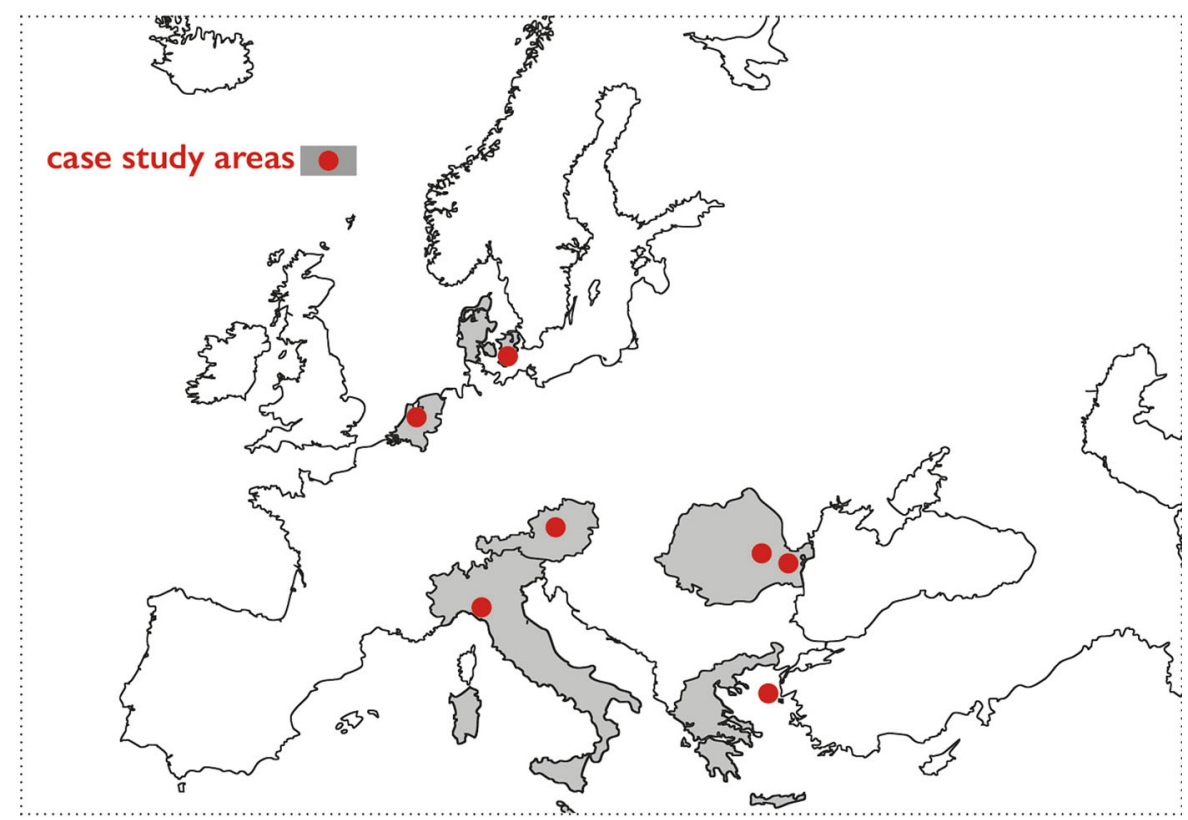


Table 1 Characteristics of case study areas. Environmental zone is based on (Metzger et al. 2005) and rural typology, predominantly $\quad$ rural $=$ rural $\quad$ population $>50 \%$, intermediate $=$ rural population $20-50 \%$, predominantly urban $=$ rural population $<20 \%$ (EuroGeographics Association 2010)

\begin{tabular}{|c|c|c|c|c|c|c|}
\hline Case study & Lesvos, GR & $\begin{array}{l}\text { Roskilde, } \\
\text { DK }\end{array}$ & Heerde, NL & Portofino, IT & $\begin{array}{l}\text { Stăncuţa, } \\
\text { RO }\end{array}$ & Răteşti, RO \\
\hline Size area (ha) & 10,800 & 21,200 & 8000 & 1800 & 25,670 & 7900 \\
\hline $\begin{array}{l}\text { Environmental } \\
\text { zone }\end{array}$ & $\begin{array}{l}\text { Mediterranean } \\
\text { South }\end{array}$ & Continental & Atlantic central & $\begin{array}{l}\text { Mediterranean } \\
\text { Mountains }\end{array}$ & Pannonian & Pannonian \\
\hline $\begin{array}{l}\text { Socio-economic } \\
\text { zone }\end{array}$ & $\begin{array}{l}\text { Predominantly } \\
\text { rural }\end{array}$ & Intermediate & $\begin{array}{l}\text { Predominantly } \\
\text { rural }\end{array}$ & $\begin{array}{l}\text { Predominantly } \\
\text { rural }\end{array}$ & Intermediate & $\begin{array}{l}\text { Predominantly } \\
\text { rural }\end{array}$ \\
\hline Dominant land use & Olive yards & Cropland & Grassland & Forest & Cropland & Cropland \\
\hline
\end{tabular}

Dominant land use is based on land use statistics

productivity increase (Bürgi et al. 2004; Hersperger and Bürgi 2009; Van Vliet et al. 2015), a key theme in the analysis of this paper. The latter was chosen because from 1992 onwards the MacSharry reform of the EU Common Agricultural Policy (CAP) introduced accompanying measures, as the first step towards de-coupling of farmers' agricultural support from production (Primdahl 2014). However, a pragmatic definition of the period had to be used based on availability of digital data for each case study area.

Land use and land cover data originated from a variety of sources, in raster and vector format. For Lesvos (GR) and Portofino (IT) land cover maps were prepared based on aerial photographs, for Stăncuţa and Răteşti (RO), Roskilde (DK) and Heerde (NL) maps were prepared based on satellite imagery. Maps were at different spatial scales but mostly at 1 ha. The number of land cover classes differed per country, from 7 in Roskilde (DK) to 13 in Heerde (NL), depending on the landscape diversity, quality of the baseline data, environmental conditions etcetera. Land cover classes were not the same for all areas, since in some cases existing maps were used, but also due to geographical differences. However, all land cover classes were converted to the same categories (see supplementary data). The data quality was checked in most areas through field work, collecting additional field data on landscape elements, e.g. for Răteşti and Stăncuţa (RO) (Snoeijer 2014), Portofino (IT) (Pedroli et al. 2013; Van der Sluis et al. 2014a), Heerde (Hauser et al. 2016) and Roskilde (DK) (Vesterager, unpublished). The land use and farming systems in each area are presented in greater detail in Kristensen et al. $(2013,2016)$. For calculations of landscape transitions the maps were converted to raster data, grid size $10 \times 10 \mathrm{~m}$.

Landscape analysis

The landscape transitions were studied for the case study areas. Any long term structural change in land use or land cover into a different type (LULC change) is defined as a landscape transition. A spatially explicit temporal analysis was carried out of the landscape change detectable on land cover maps. By distracting the land cover grids for selected time steps for each study area a land-change matrix was calculated. This resulted in matrices with the gross LULC change, which allows to see e.g. what land cover type changed into forest (afforestation), but also what was converted from forest into another land cover type. Benini et al. (2010) labelled LULC change as transitions for a study area in the Italian Alps, which was adapted for the observed changes in the case study areas. The possible transitions are shown in Table 2: they range from abandonment and urbanisation to agricultural intensification or extensification. The transitions which took place within the case study areas over the past decades were recorded. Where the landscape had not changed in the assessed period, it was classified as 'persistent'.

Changes from farmland into forest were classified as 'Afforestation', but if farmland converted e.g. into shrubland or macchia, it was classified as 'Abandonment'. Where natural areas changed into farmland, it was marked as 'Agricultural reclamation', however, if farmland converted from a less intensive crop towards an intensive crop (e.g. grassland into annual crops) it was marked as 'Conversion-intensive'. Examples of 
Table 2 Possible landscape transitions in the case study areas (adapted from Benini et al. 2010)

\begin{tabular}{lll}
\hline Code & Landscape transition & Description \\
\hline $\mathrm{P}$ & Persistence & Areas with no change in land use \\
$\mathrm{A}$ & Abandonment & Abandoned urban or farming areas \\
$\mathrm{U}$ & Urbanisation & Change into urban area \\
$\mathrm{D}$ & Deforestation & Forest converted into other land use \\
$\mathrm{Af}$ & Afforestation & Forest encroachment and plantation \\
$\mathrm{Ra}$ & Agricultural reclamation & Conversion non-farmland into agricultural use \\
$\mathrm{Ci}$ & Conversion-intensive & Agricultural area with conversion into more intensive use \\
$\mathrm{Ce}$ & Conversion-extensive & Agricultural area with conversion into more extensive use \\
$\mathrm{E}$ & Exceptionality & Unusual conversion \\
\hline
\end{tabular}

conversion-intensive can be: conversions of arable land to permanently irrigated areas; permanent crops (vineyards, orchards, olive groves) to irrigated and non-irrigated arable land; and conversions of pasture to arable land and permanent crops (EEA 2017). Where it was unlikely that a conversion had taken place, e.g. from urban area towards cropland, or forest towards sea, it was labelled as 'Exceptionality'. In Răteşti (RO) the change of farmland into river might be due to the flooding regime of the Danube.

The purpose of a landscape assessment should ideally guide the approach and possibly the choice of indicators (Wascher 2004). Several authors suggest that the best indicators to describe and quantify landscape transitions are land use and land cover (Plieninger 2006; Benini et al. 2010), and landscape structure (Van der Sluis et al. 2004; Levin and Jepsen 2010). The landscape structure refers to size, shape, arrangement and distribution of individual landscape elements (Walz 2011). These characteristics are likely to be affected by a range of parameters, e.g. agricultural policies, land ownership or farming technology. Landscape elements and landscape structure affect the life support functions of the landscape, in particular biodiversity, landscape connectivity and the potential to sustain wildlife populations (Van der Sluis et al. 2004). Given the limited availability of data, we used the LULC analysis to deduct the impact on landscape structure.

The LULC change was calculated relative to the total size of the case study area in ArcGis 10.2 (ESRI 2011), and Google Maps and field investigations were used to verify observed changes.

Land conversion matrices were prepared, and analysed on the type of transition occurring. This comparison allows us to draw conclusions regarding the similarities and differences in change processes and their impacts in different regions in Europe.

Assessment of landscape services

Landscape services can be assessed with different approaches and methods, as demonstrated by an increasing body of literature. Gulickx et al. (2013) used combined sources to map services: map data, point observations, and additional information from databases. Van Berkel and Verburg (2014) engaged in participatory mapping, and participants were asked to value the landscape for recreation, aesthetic beauty, cultural heritage, inspiration and spirituality. Crouzat et al. (2015) combined field surveys and inventories with map analysis. A detailed assessment of various landscape services was done by Bastian et al. (2014), testing the concept in five case studies in Germany. All these studies were used as inspiration for the approach followed in this paper: map analysis, field inventories, and relating LULC change to services.

A semi-quantitative approach has been followed to assess the change in landscape services based on the analysis of LULC change. Selected landscape services for this assessment are: food, feed, timber, habitat and residential service (Table 3). A selection was made of services that are easily identified based on a one-onone relationship with land cover or land use. The diversity of maps for the case studies, the differences in classification of land use or cover, some differences in scale, and the general absence of features of landscape structure limited the number of services that could be mapped. Therefore additional landscape surveys were done for Heerde (NL) and Stăncuţa and Răteşti (RO) (Snoeijer 2014; Hauser et al. 2016) and an updated map was prepared for Portofino (IT). 
Table 3 Identified landscape services and service category

\begin{tabular}{lll}
\hline Landscape service & Service category & Specific land use \\
\hline Food & Provisioning services & Arable, grassland \\
Feed & Provisioning services & Grassland \\
Timber & Provisioning services & Forested/natural area \\
Habitat & Supporting services & Natural/abandoned \\
Residential & Cultural services & Built-up area \\
\hline
\end{tabular}

Although the selected services might be challenged to be subjective, this selection is relevant in the wider European context and commonly used in other studies. Also, the provision of these services have been demonstrated to change in time as a result of landscape transitions (Vallés-Planells et al. 2014; Bürgi et al. 2015).

The provisioning service of food and feed production was defined based on the increase or decrease in cropland and grazing land area (farmed land in relation to land abandonment), as well as the change in productivity, which can be assessed based on intensification or extensification. Changes in timber provision are estimated based on forest cover change. The habitat provision is assessed based on an interpretation of change in natural areas and abandoned land, which over time transforms into forest again. The residential service is derived from the 'built-up' area in the case studies, which to a very limited extent might include some other functions. For each study area we calculated the LULC \% change, and what landscape transition takes place (Table 2, and supplementary data).The landscape transition was then linked to the change in service, so if 60 ha agricultural land is converted into urban area, this would mean a decrease in food and feed services but an increase in residential services. The rate of change in service provision was rated on the basis of the $\%$ change as increase. strong increase, decrease, strong decrease or negligible (Table 5).

\section{Results}

The observed landscape transitions are presented in this section, followed by the estimated impact on the provided landscape services, then the multiscale drivers which cause these changes with emphasis on changing policies and regulations regarding land use and environmental quality. The transition matrices for the case study areas are presented as supplementary data available on the journal website.

Landscape transitions in the case study areas

The observed average annual change is $0.55 \%$ per annum (p.a.), with lowest change on Lesvos (GR) and in Roskilde (DK), and the highest for Heerde (NL) and Portofino (IT). The change over time averaged for all areas is $10 \%$ for the entire studied period (Table 4). The high degree of change in Portofino, where $25 \%$ of the landscape changed from 1974 to 2000 (or $0.96 \%$ p.a.), is mostly the result of land abandonment and the occurrence of the frequent wild fires in the area. In Roskilde (DK) a relatively small long-term change of $0.21 \%$ p.a. was found, since in particular farmland was very stable, and mostly other landscape use categories changed over time (Kristensen et al. 2009). The average annual change was lowest in Lesvos (GR) with $0.11 \%$ p.a. The total annual change is on average $10.65 \%$, with a particular high rate of change in Portofino (24.9\% change) and Stăncuţa (15.7\%), but except for Lesvos (2.4\%) in all areas also considerable change: $4.6 \%$ (Roskilde) or more (Heerde $7.8 \%$, Rătesţi 8.3\%).

The urbanisation is the most dominant transition in the form of urban sprawl, houses or sometimes warehouses are constructed in the countryside or expansion is more concentrated near towns and villages. The increase of urban area (which includes generally land take by infrastructure) does not exceed $2.8 \%$ (in Răteşti, RO). In Roskilde (DK), the most urbanized area among the study areas, urbanisation increased by $1.8 \%$ and in Heerde (NL) by $0.8 \%$. On Lesvos migration has occurred from rural villages into the city of Mytilini and suburban locations, as well as into satellite villages with accompanying roads, sports and recreation facilities, expansion of ports, marinas, etc. Conversion - intensification seems dominant in Heerde (NL) due to conversion of grassland and maize 
Table 4 LULC change in case study areas in recent decades

\begin{tabular}{lllll}
\hline Case study area & Period & Years & Change $(\%$ of area) & Annual change $(\%$ of area $)$ \\
\hline Lesvos (GR) & $1981-2004$ & 23 & 2.6 & 0.11 \\
Roskilde (DK) & $1990-2011$ & 21 & 4.6 & 0.21 \\
Heerde (NL) & $1996-2004$ & 8 & 7.8 & 0.98 \\
Portofino (IT) & $1974-2000$ & 26 & 24.9 & 0.96 \\
Stăncuţa (RO) & $1980-2003$ & 23 & 15.7 & 0.68 \\
Răteşti (RO) & $1980-2003$ & 23 & 8.3 & 0.36 \\
\hline
\end{tabular}

into other crops and orchards, while in Răteşti (RO) it reflects a shift of grassland into cropland (7.5\%). A reverse shift towards agricultural extensification occurs mostly in the same areas, albeit at a lower level $(2.2 \%$ and $1.6 \%$ respectively). Agricultural reclamation (conversion from e.g. forest into farmland) is very limited, it involves only $1.3 \%$ in Portofino, and lower rates were found for other areas. At the same time land was abandoned in Portofino so the net change is negligible. Land abandonment as a category of change was observed mostly in the areas of marginal farming like Portofino (IT) (5.4\%), but was also observed in some other study areas like Răteşti (RO) $(0.4 \%)$. The forested areas increase as afforestation exceeds the deforestation, in all areas except for Portofino (IT). The afforestation is $2 \%$ on average, and deforestation is negligible in most areas. In Portofino, however, deforestation affects 271 ha (14.8\%), mostly caused by a change from macchia into grassland (206 ha). Exceptionality, finally, explains the unexpected or unlikely changes. The exceptionality for Stăncuţa (RO) stands out, however, most (560 ha) is due to cropland which was later classified as 'river'. This can be explained by the flooding of the Danube in 2003 and timing of the aerial photography, which resulted in an 'increase' of 550 ha of river.

\section{Changing landscape services provision}

The landscape transitions have an impact on the landscape services in the case study areas, e.g. when in Răteşti the decrease in livestock feed (grassland) results in an increase in food production. Figure 3 and Table 5 present how landscape services might have changed, based on the observed landscape transitions (Table 2). The expansion of built up areas and second homes on Lesvos contributes to the increased residential services. Tourism increased as a result of newly built second houses as well as tourist apartments (Kizos et al. 2009).

Striking for Roskilde (DK) is the increased residential service, driven by processes of urbanisation of the peri-urban countryside. In 2001 the total length of planted hedgerows was $331 \mathrm{~km}$ for more than 2200 elements, planted to improve public goods (e.g. biodiversity, climate change mitigation) or fulfil personal and family ambitions and values (Van der Sluis et al. 2014b; Kristensen et al. 2016), and hedgerows thus further increased habitat provision. The timber potential and habitat provision increased as a result of public afforestation, nature restoration or measures to improve water quality. There is limited change of service provision in Heerde (NL), which may be due to the relatively short period for comparison, 1995-2004. The food production capacity increased, due to intensification of land use, mostly a shift from grass and maize towards more intensive crops. Dominant changes in service provision in Portofino (IT) due to the landscape transitions from 1974 to 2000 are: a strong decrease in timber potential, an increase in residential function and in habitat provision (Table 5). The decrease in potential timber provision is likely to be related to the frequent wild fires occurring, resulting in the forest vegetation being set back to sparse vegetation and macchia. Portofino is attractive for second house owners, and increased residential function and tourism in the buffer zone of the Nature Park were observed. The poor profitability of agricultural production leads to negligence and land abandonment of farms and terraces: olive groves have disappeared and chestnut plantations declined, resulting in development of macchia and forest. Abandonment followed by succession may have positive effect on habitat provision (Pedroli et al. 2013).

Changes in landscape services have been very limited in Stăncuţa, and slightly higher in Răteşti (RO). In both Stăncuţa and Răteşti there was a slight 
Average landscape transition

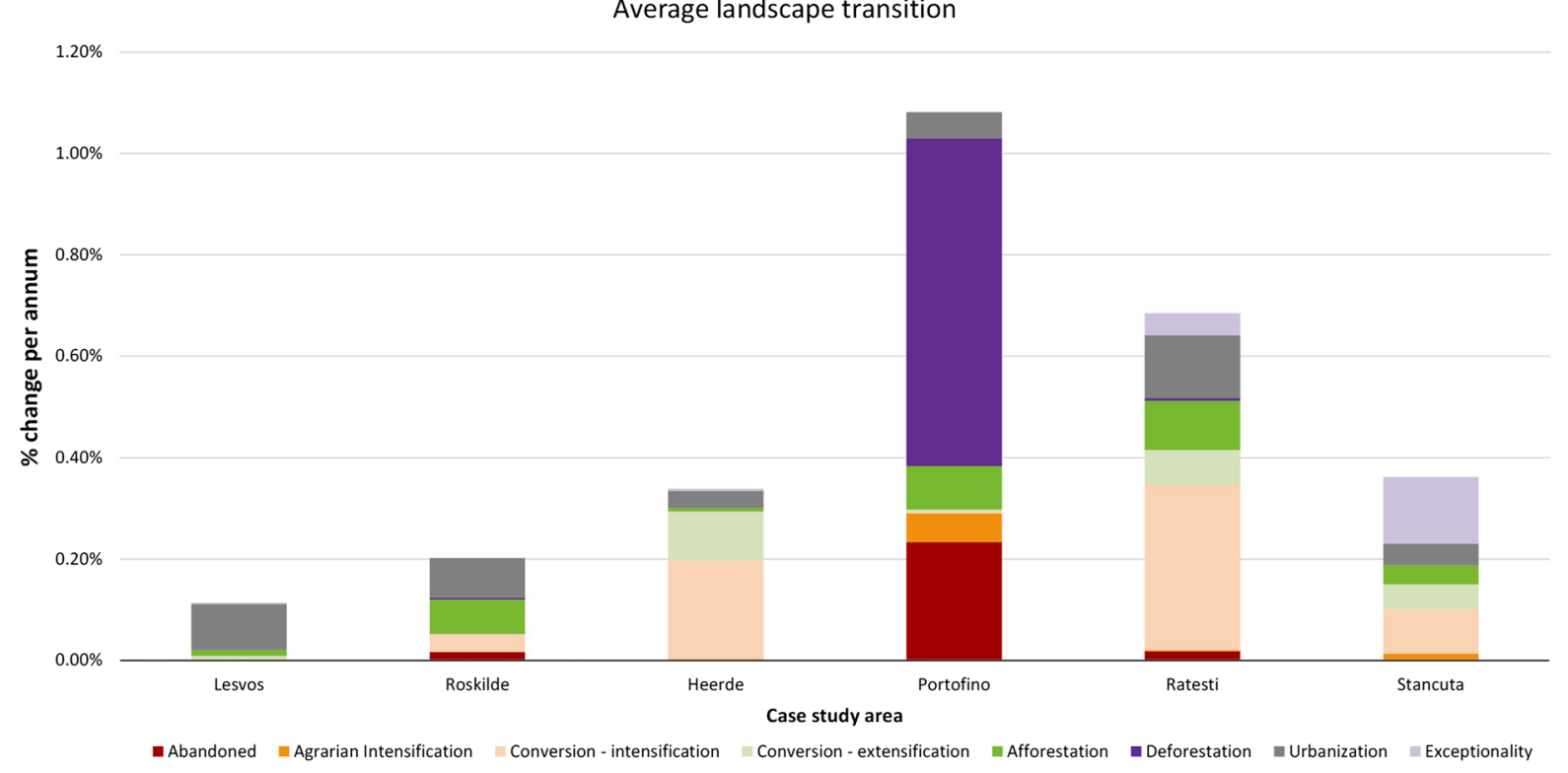

Fig. 3 Landscape transitions in the case study areas (annual \% change)

Table 5 Change in landscape service provision in study areas: + increase $(1 \leq 4 \%)$, ++ strong increase $(\geq 4 \%)$, decrease $(-1 \leq-4 \%),--$ strong decrease $(<-4 \%)$, negligible $(-1<1 \%$ change $)$

\begin{tabular}{lllllll}
\hline Service provision & \multicolumn{2}{l}{ Case study } & & \\
\cline { 2 - 6 } & Lesvos, GR & Roskilde, DK & Heerde, NL & Portofino, IT & Răteşti, RO & Stăncuţa, RO \\
\hline Food (area potential) & $\circ$ & $\circ$ & $\circ$ & $\circ$ & $\circ$ & $\circ$ \\
Food (productive capacity) & $\circ$ & $\circ$ & ++ & $\circ$ & + & $\circ$ \\
Feed & $\circ$ & & $\circ$ & $\circ$ & - & + \\
Timber potential & $\circ$ & + & $\circ$ & ++ & $\circ$ & + \\
Habitat & $\circ$ & + & $\circ$ & + & + \\
Residential & + & + & $\circ$ & & + \\
\hline
\end{tabular}

increase in residential services, and a decrease in feed production. Grassland was converted into cropland, forest and some built up-up area. The food production capacity though showed a large increase in Răteşti, as almost 600 ha of grassland was converted into cropland. Also the potential timber production service increased. The overall observed landscape transitions indicate a dominant trend of intensification. The afforestation outweighs the deforestation, afforestation schemes have been supported by EU since 1989 and are now part of the Rural Development Programme.
All study areas show an urbanisation trend, with land take ranging from 0.8 to $2.8 \%$ (Fig. 3, and supplementary data). This results in an expansion of houses, so increased residential services. The extent of this urban transition depends particularly on spatial planning, which is guided mostly by national or regional policies. In particular in Răteşti $(2.8 \%$ increase) and Lesvos (2.0\%) the urban expansion is concentrated or clustered around existing built-up areas and this seems not so much an intentional effect, but rather the consequence of lack of or ineffective policy (Vesterager et al. 2016). In Roskilde (1.8\%) the built-up areas are partly scattered in the countryside. 


\section{Discussion}

Trends in landscape transition

The large-scale trends affecting local landscape transitions lead to a diversity of outcomes and impacts on landscape services. This diversity was explored by studying cases in various regions of Europe. The results show three important processes (Fig. 3). (1): urbanisation occurs in almost all case studies, with an increase of built-up area exceeding $0.03 \%$ /year, the highest rates occur in Răteşti (0.12\%/year) and Lesvos (0.09\%/year). (2): Land conversion is apparent in the Netherlands and Romania, with intensification taking place in Heerde (0.19\%/year), and Romania: Stăncuţa (0.09\%/year) and Răteşti (0.33\%/year), and extensification-to a lesser extent-in the same cases, indicating high volatility in land use. (3): Afforestation is observed over considerable areas (up to $0.07 \%$ /year in Roskilde, 0.09\%/year in Portofino and $0.10 \%$ in Răteşti) and exceeds deforestation in all areas, except for Portofino (IT) where wildfires have resulted in a net decrease in forest area. A further important trend of landscape transition is land abandonment as observed to a limited extent in Roskilde (DK) and Răteşti (RO), and as an important transition especially in Portofino (IT).

Comparable trends have been observed for Europe as a whole by Fuchs et al. (2013) and Fuchs et al. (2015), assessing land cover change on the basis of detailed map and remote sensing data. They observe that urbanisation (all settlement gains), re-/afforestation (forest gains on basis of cropland and grassland areas), and cropland/grassland dynamics are the major land change processes in Europe in the past century (Fuchs et al. 2015).

A study of hotspots of land use change across Europe at detailed level revealed that most widespread land use change between 1990 and 2006 was cropland decline, followed by forest area expansion and pasture increase (Kuemmerle et al. 2016). Although Stürck and Verburg (2016) warn that the selection of scale and used indicators very much influence the findings of land use transition studies, this trend is confirmed at the smaller spatial scale in this study, where we found that in most cases also the food production potential decreased and timber production increased. Kuemmerle et al. (2016) found that overall changes were moderate, ranging from $-13.4 \%$ for permanent crops to $+6.5 \%$ for meadows and pastures, and $+21 \%$ for urban areas between 1990 and 2006, which is similar to our findings (Table 4).

Timeframe of landscape transitions

While the observed rates of LULC change per year may not seem very large, the proportion of the landscape affected by LULC change may cumulate to considerable areas. For example, the LULC transitions to urbanized area on Lesvos (GR) imply an expansion of built-up area from 424 ha to 648 ha within 23 years, which is an increase of $53 \%$ (see also supplementary data). Also the timeframe investigated influences the findings. In the present paper the use of a timeframe of almost 25 years may conceal that large changes and in fact opposite changes have occurred in the preceding period. Reconstructing the change during the entire 20th century based on global data sets, Fuchs et al. (2015) found that the overall gross change was as much as $56 \%$. In this context especially the Mediterranean region can be considered a hotspot for landscape transitions in the past century (Fuchs et al. 2013). Bürgi et al. (2017) came to a change rate of 35.61 ha/year in Lesvos, this would result in 819 ha change, which is much higher than the 282 ha change we found. The case study was however in a more arid part of Lesvos, with less olive growing and more grazing.

Shifts in the orientation of land use towards production, consumption or protection

Positioning the observed landscape transitions in Holmes' conceptual framework for the use of the rural space, the main trends observed in each case area can better be interpreted in their landscape consequences. A general trend is observed from production towards consumption for Lesvos (GR) and Roskilde (DK), a slight shift from multifunctional towards protection for Stăncuţa and more prominently for Portofino, and a shift towards intensification and increased production for Heerde (NL) and Răteşti (Fig. 4).

This shift towards intensification in Răteşti concurs with the existence of large-scale but not very intensive farming in Romania before the political changes of 1989. The ample available land at relatively low cost allowed farmers to intensify and reduce the yield gap 


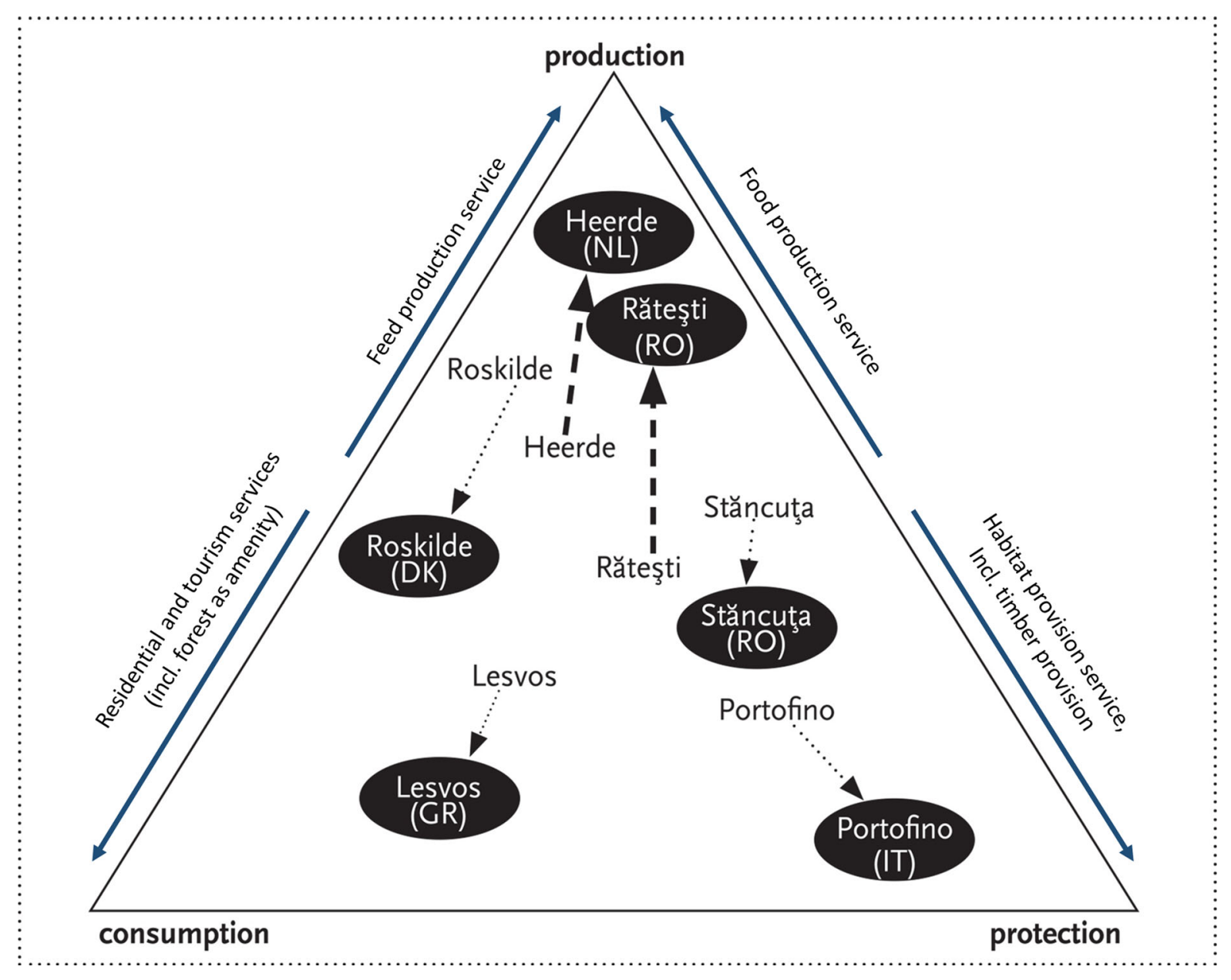

Fig. 4 Observed changes in use of rural space, following Holmes, and changes in ES

compared to other EU member states. In Heerde, farmland of ceased farms is taken over by neighbouring (large) farms. The strong market pressure in Heerde results in frequently changing crops or changing landscape elements, which was also found by Hauser et al. (2016).

The land use orientation towards protection has increased in Portofino, but since farm houses are sometimes taken over by non-farmers, the landscape transition has also a certain consumption aspect. Some multifunctional farming continues here but production is very limited (Van der Sluis et al. 2014a).

The trend of land use orientation towards consumption has a rather different expression on Lesvos (GR) than in Roskilde (DK). In Roskilde the increase in residential functions is driven by processes of urbanisation. The impact has not led to very significant changes north of Roskilde, as it has mostly occurred as "hidden" urbanisation, where former farms have been converted to residential or other economic uses than agriculture (Busck et al. 2006; Præstholm et al. 2006). A strict zoning policy has prevented large-scale urban sprawl (Busck et al. 2008), but east of Roskilde still considerable urban development took place. An important consequence of land take by urbanisation is the fragmentation of the landscape which results in a decrease of the habitat service. A decrease in landscape services provision is one of the negative aspects of urban land take, as highlighted in EEA (2015). Also an increase in timber is noted. Afforestation contributes to timber or firewood production, but forest can also be planted for amenity reasons-in Roskilde, like in other areas, the afforestation areas were realised in or near urban areas for recreational purposes and for 
drinking water protection (see arrows along the edges of the triangle in Fig. 4). We hypothesize that cultural services are most likely associated with multifunctional land use, and thus cultural services generally decline with a shift towards production, protection or consumption. Only dedicated management of consumption or protection landscapes may safeguard sustainable provision of cultural services (such as heritage tourism and ecotourism respectively); the absence of production functions, however, may make the sustainable management difficult.

On Lesvos farming has not been very profitable since olive subsidies were reduced or abolished in the 1990s, but at the same time living standards increased and funds became available to develop (second) houses in the countryside, and an increasing orientation towards consumption is here the most important transition in the studied period.

Multifunctional land use (combining production, consumption and protection) can be a means to meet the many demands that are at stake in our landscapes, but this also calls for political prioritisation and a more rational use of land resources. In most cases studied here, a trend away from production towards consumption or protection is dominant, however, in Heerde (NL) and Răteşti (RO) intensification is prevalent, well beyond multifunctionality, while in typical cultural landscapes like Portofino or Lesvos land abandonment also leads away from multifunctionality.

The $25 \%$ overall LULC change in Portofino from 1974 till 2000 resulted from natural hazards such as wildfire, as well as (successful) environmental policies and legislation which led to landscape protection and guided tourism development (Pedroli et al. 2013). Tourism increased, while agricultural production declined. Similar change processes (though at a much smaller scale) take place on Lesvos (GR), but without considerable change in landscape, since the terraced landscape can be seemingly quite 'inert': initially the decay is not very conspicuous (Vos and Stortelder 1992; Van der Sluis et al. 2014a). Terres et al. (2015) identify Italy and Greece as countries at risk for land abandonment. Abandonment is a consequence of the high labour demand for maintenance of the traditional slope terraces in the Mediterranean (Van der Sluis et al. 2014a, b). For part of the terraces in Portofino and Lesvos the decline is still invisible, but it will eventually lead to erosion, collapse of dry-stone terrace walls and further decline of landscape services such as those based on the scenic quality, i.e. inspiration and tourism.

The role of policy in landscape transitions

As Bürgi et al. (2015) wrote, "The recognized ES and the driving forces are interlinked, as only recognized ES can trigger innovations, can lead to debates on wanted adaption of legal frameworks or put pressure on policy making." The role of policy, as they point out, is therefore crucial in managing landscape services. Policymakers respond to the landscape transitions and may attempt to guide landscape changes in a certain direction through directives and policies. At the same time, the link between policy and landscape change (and thus landscape transitions) is indirect, and hard to prove (see e.g. Pinto-Correia et al. 2018 p. 198 and further).

Implementing the services concept into planning requires a good assessment of the context, objectives and capacities (Albert et al. 2014a). From the Roskilde (DK) and Heerde (NL) case studies it is known that zoning has a big influence on the location of residential areas, and spatial planning decreases the land use change options (Van den Brink et al. 2006; Primdahl et al. 2009). Most of the changes observed in Roskilde (DK) were conversion of cropland into forest or settlements. The combined drivers affect in particular the choice of crops, intensity and scale of farming and agricultural production system, but also to some extent demography, e.g. migration within the European Union (Swaffield and Primdahl 2010; Primdahl et al. 2013). This subsequently affects labour availability, particularly pronounced in Romania or on Lesvos (GR), where outmigration resulted in shortages in farm labour (Van Vliet et al. 2015), in particular for skilled, laborious work such as terrace maintenance (Van der Sluis et al. 2014a; Kristensen et al. 2016).

Summarising, it appears to be very difficult from our case studies to deduce how far policies acted as a direct driver of the change processes observed, although they likely influenced the transitions indirectly.

\section{Conclusions}

The goal of this paper is to assess what implications landscape transitions have for the provision of 
landscape services, and whether these changes can be related to specific drivers of change. Landscape transitions are reported for six case studies which represent a range of various European rural landscapes. We demonstrate that different types of services, i.e. provisioning, cultural or supporting services, are affected in different ways. For this purpose Holmes' conceptual framework for the use of the rural space, appeared to be convenient to explain the observed landscape transitions and resulting shifts in landscape services (Holmes 2008). Although the changes in landscape elements do affect the servicesin this assessment in particular the cultural servicesspatial data alone is insufficient to assess the impacts of landscape transition on landscape structure and pattern. The landscape pattern is probably most diverse in the 'multifunctional' mode of land use in the centre of Holmes' triangle. Many policies however drive towards either production, protection or consumption, tending towards less diverse landscape patterns, which can presumably be related to a decrease in cultural services.

Some specific conclusions are:

- Conversion of farms for residential purposes results in an increasing share of the population that has no real attachment to the farming sector (Verhoeve et al. 2012, 2015; Ruoso 2018). This is confirmed in our case studies in Heerde (NL) and Roskilde (DK).

- The LULC change (on average some $10 \%$ over 25 years) is surprisingly small considering the time period if compared to other studies (e.g. Fuchs et al. 2013, 2016), still, in some areas it is almost $1 \%$ per annum. This 'limited'change conceals that some transitions may have a relatively large impact on landscape services in the countryside.

- Most land abandonment is observed in case studies in depopulating farming areas in Europe, particularly in mountainous regions and southern Europe. Portofino (IT) and Lesvos (GR) exemplify traditional land use systems (low intensity perennial crops and livestock raising), which experience an increase in natural habitat and tourism services, and a decline in agricultural production. Tourism may provide options to preserve traditional farming, and increase aesthetic values.

- The cultural services considered (residential function) are generally governed by the regional and national spatial planning framework, and in the current era of strong decentralisation tendencies all over Europe, they are definitely less well secured by national or regional policies. Habitat services are mostly vested in the EU-Biodiversity Directives and national forest policies. These directives and regional environmental zoning plans do limit the possibilities for landscape transitions to a certain extent, but the impact of these Directives has not been very large for the studied period in the cases described.

Concluding, although circumstantial evidence points to substantial effects of EU and national policies on landscape services, often unintentionally but negatively influencing cultural identity and landscape character, more research is needed on the exact cause-effect relationships between policies and perceived landscape values.

Open Access This article is distributed under the terms of the Creative Commons Attribution 4.0 International License (http:// creativecommons.org/licenses/by/4.0/), which permits unrestricted use, distribution, and reproduction in any medium, provided you give appropriate credit to the original author(s) and the source, provide a link to the Creative Commons license, and indicate if changes were made.

\section{References}

Albert C, Aronson J, Fürst C, Opdam P (2014a) Integrating ecosystem services in landscape planning: requirements, approaches, and impacts. Landscape Ecol 29(8):1277-1285

Albert C, Hauck J, Buhr N, von Haaren C (2014b) What ecosystem services information do users want? Investigating interests and requirements among landscape and regional planners in Germany. Landscape Ecol 29(8):1301-1313

Antrop M, Brandt J, Loupa-Ramos I, Padoa-Schioppa E, Porter J, Van Eetvelde V, Pinto-Correia T (2013) How landscape ecology can promote the development of sustainable landscapes in Europe: the role of the European Association for Landscape Ecology (IALE-Europe) in the twenty-first century. Landscape Ecol 28(9):1641-1647

Arler F, Jørgensen MS, Sørensen EM (2017) Prioritering af Danmarks areal i fremtiden. Aalborg University, Aalborg

Bastian O, Grunewald K, Syearbe R-U, Walz U, Wende W (2014) Landscape services: the concept and its practical relevance. Landscape Ecol 29(9):1463-1479

Benini L, Bandini V, Marazza D, Contin A (2010) Assessment of land use changes through an indicator-based approach: a case study from the Lamone river basin in Northern Italy. Ecol Ind 10(1):4-14 
Brandt J, Vejre H (2003) Multifunctional landscapes: Volume II: Monitoring, Diversity and Management. WIT Press, Billerica

Bürgi M, Bieling C, von Hackwitz K, Kizos T, Lieskovský J, Martín MG, McCarthy S, Müller M, Palang H, Plieninger T, Printsmann A (2017) Processes and driving forces in changing cultural landscapes across Europe. Landscape Ecol 32:1-16

Bürgi M, Hersperger A, Schneeberger N (2004) Driving forces of landscape change-current and new directions. Landscape Ecol 19(8):857-868

Bürgi M, Silbernagel J, Wu J, Kienast F (2015) Linking ecosystem services with landscape history. Landscape Ecol 30(1):11-20

Busck AG, Kristensen SP, Præstholm S, Primdahl J (2008) Porous landscapes-the case of Greater Copenhagen. Urban For Urban Green 7(3):145-156

Busck AG, Kristensen SP, Præstholm S, Reenberg A, Primdahl J (2006) Land system changes in the context of urbanisation: examples from the peri-urban area of Greater Copenhagen. Geografisk Tidsskrift Danish Journal of Geography 106:21-34

Carvalho-Ribeiro SM, Madeira L, Pinto-Correia T (2013) Developing comprehensive indicators for monitoring rural policy impacts on landscape in Alentejo, southern Portugal. Geografisk Tidsskrift Danish Journal of Geography 113(2):87-96

Cormont A, Siepel H, Clement J, Melman TCP, WallisDeVries MF, van Turnhout CAM, Sparrius LB, Reemer M, Biesmeijer JC, Berendse F, de Snoo GR (2016) Landscape complexity and farmland biodiversity: Evaluating the CAP target on natural elements. J Nat Conserv 30:19-26

Crouzat E, Mouchet M, Turkelboom F, Byczek C, Meersmans J, Berger F, Verkerk PJ, Lavorel S (2015) Assessing bundles of ecosystem services from regional to landscape scale: insights from the French Alps. J Appl Ecol 52(5):1145-1155

EEA (2010) The European environment—state and outlook 2010 (SOER 2010)

EEA (2015) The European environment-state and outlook 2015: synthesis report. European Environment Agency, Copenhagen, p 205

EEA (2017) Landscapes in transition. An account of 25 years of land cover change in Europe. European Environmental Agency, Copenhagen,

ESRI (2011) ArcGIS Desktop: Release 10.2. Environmental Systems Research Institute, Redlands, CA, USA.,

EuroGeographics Association (2010) A new urban-rural typology for NUTS 3 regions

Feranec J, Soukup T, Hazeu G, Jaffrain G (2016) European landscape dynamics: CORINE land cover data. CRC Press, Boca Raton

Forest Europe (2015) State of Europe's forests 2015. Status and trends in sustainable forest management in Europe. Ministerial Conference on the Protection of Forests in Europe, Madrid,

Fuchs R, Herold M, Verburg PH, Clevers JGPW (2013) A highresolution and harmonized model approach for reconstructing and analysing historic land changes in Europe. Biogeosciences 10(3):1543-1559
Fuchs R, Herold M, Verburg PH, Clevers JGPW, Eberle J (2015) Gross changes in reconstructions of historic land cover/use for Europe between 1900 and 2010. Glob Change Biol 21(1):299-313

Fuchs R, Schulp CJ, Hengeveld GM, Verburg PH, Clevers JG, Schelhaas MJ, Herold M (2016) Assessing the influence of historic net and gross land changes on the carbon fluxes of Europe. Glob Change Biol 22(7):2526-2539

Gulickx MMC, Verburg PH, Stoorvogel JJ, Kok K, Veldkamp A (2013) Mapping landscape services: a case study in a multifunctional rural landscape in The Netherlands. Ecol Ind 24:273-283

Hauser L, Van der Sluis T, Giezen M (2016) The Role of Farm Management Characteristics in Understanding the Spatial Distribution of Landscape Elements: a Case Study in the Netherlands. Rural Landsc 3(1):7

Hersperger AM, Bürgi M (2009) Going beyond landscape change description: quantifying the importance of driving forces of landscape change in a Central Europe case study. Land Use Policy 26(3):640-648

Holmes J (2008) Impulses towards a multifunctional transition in rural Australia: interpreting regional dynamics in landscapes, lifestyles and livelihoods. Landsc Res 33(2):211-223

Holmes J (2012) Cape York Peninsula, Australia: a frontier region undergoing a multifunctional transition with indigenous engagement. J Rural Stud 28(3):252-265

Hornigold K, Lake I, Dolman P (2016) Recreational use of the countryside: no evidence that high nature value enhances a key ecosystem service. PLoS ONE 11(11):e0165043

Huntsinger L, Oviedo JL (2014) Ecosystem Services are Socialecological Services in a Traditional Pastoral System: the Case of California's Mediterranean Rangelands. Ecol Soc 19(1)

Kizos T, Dalaka A, Petanidou T (2009) Farmers' attitudes and landscape change: evidence from the abandonment of terraced cultivations on Lesvos, Greece. Agric Human Values 27(2):199-212

Klijn JA (2004) Driving forces behind landscape transformation in Europe, from a conceptual approach to policy options. In: Jongman R (ed) The new dimensions of the European landscape. Springer, The Netherlands, pp 201-217

Kristensen SBP, Busck AG, van der Sluis T, Gaube V (2016) Patterns and drivers of land use change in selected European rural landscapes. Land Use Policy 57:786-799

Kristensen SBP, Gravsholt Busck AG, Cosor G, Gaube V, Pavlis E, Van der Sluis T, Terkenli T, Vădineanu A (2013) Landscape changes in Europe: upscaling results from case studies and cross-region comparisons. Deliverable 1.4 VOLANTE. http://volante-project.eu/images/stories/DELI VERABLES/VOLANTE_D1.4_Synthesis_report_-_Upscal ing_results_and_cross-region_comparisons.pdf. VOLANTE Project reports, Copenhagen. Accessed 1 Nov 2018

Kristensen SBP, Reenberg A, Peña JJ (2009) Exploring local rural landscape changes in Denmark: a human-environmental timeline perspective. Geografisk Tidsskrift Danish J Geogr 109(1):47-67

Kuemmerle T, Levers C, Erb K, Estel S, Jepsen MR, Müller D, Plutzar C, Stürck J, Verkerk PJ, Verburg PH, Reenberg A (2016) Hotspots of land use change in Europe. Environ Res Lett 11(6):064020 
Levin G, Jepsen MR (2010) Abolition of set-aside schemes, associated impacts on habitat structure and modelling of potential effects of cross-farm regulation. Ecol Model 221(22):2728-2737

MA (2005) Millennium ecosystem assessment, ecosystems and human well-being: synthesis. Island Press, Washington, DC

Metzger MJ, Bunce RGH, Jongman RHG, Mücher CA, Watkins JW (2005) A climatic stratification of the environment of Europe. Glob Ecol Biogeogr 14(6):549-563

Oduro KA, Mohren GMJ, Peña-Claros M, Kyereh B, Arts B (2015) Tracing forest resource development in Ghana through forest transition pathways. Land Use Policy 48:63-72

Opdam P, Coninx I, Dewulf A, Steingröver E, Vos C, van der Wal M (2015) Framing ecosystem services: affecting behaviour of actors in collaborative landscape planning? Land Use Policy 46:223-231

Pedroli B, Tagliasacchi S, Van der Sluis T, Vos W (2013) Ecologia del paesaggio del Monte di Portofino/Landscape Ecology of the Monte di Portofino. (bilingual ItalianEnglish edition) [incl. Landscape-ecological map 1:10,000], Wageningen

Pinto-Correia T, Guiomar N, Guerra CA, Carvalho-Ribeiro S (2016) Assessing the ability of rural areas to fulfil multiple societal demands. Land Use Policy 53:86-96

Pinto-Correia T, Primdahl J, Pedroli B (2018) European landscapes in transition: Implications for Policy and Practice. Cambridge University Press, Cambridge

Plieninger T (2006) Habitat loss, fragmentation, and alteration-quantifying the impactof land-use changes on a Spanish Dehesa landscape by use of aerial photography and GIS. Landscape Ecol 21(1):91-105

Plieninger T, Bieling C, Fagerholm N, Byg A, Hartel T, Hurley P, López-Santiago CA, Nagabhatla N, Oteros-Rozas E, Raymond CM, Van der Horst D, Huntsinger L (2015) The role of cultural ecosystem services in landscape management and planning. Curr Opin Environ Sustain 14:28-33

Plieninger T, van der Horst D, Schleyer C, Bieling C (2014) Sustaining ecosystem services in culturallandscapes. Ecol Soc 19(2):59

Præstholm S, Reenberg A, Kristensen SP (2006) Afforestation of European landscapes: how do different farmer types respond to EU agri-environmental schemes? GeoJournal 67(1):71-84

Primdahl J (2014) Agricultural landscape sustainability under pressure: policy developments and landscape change. Landsc Res 39(2):123-140

Primdahl J, Kristensen LS, Swaffield S (2013) Guiding rural landscape change: current policy approaches and potentials of landscape strategy making as a policy integrating approach. Appl Geogr 42:86-94

Primdahl J, Vejre H, Buschk A, Kristensen L (2009) Planning and development of the fringe landscapes. In: Van der Valk A, Van Dijk T (eds) Regional planning for open space. Taylor and Francis, London/New York

Rounsevell MDA, Pedroli B, Erb K-H, Gramberger M, Busck AG, Haberl H, Kristensen S, Kuemmerle T, Lavorel S, Lindner M, Lotze-Campen H, Metzger MJ, Murray-Rust D, Popp A, Pérez-Soba M, Reenberg A, Vadineanu A,
Verburg PH, Wolfslehner B (2012) Challenges for land system science. Land Use Policy 29(4):899-910

Ruoso L-E (2018) The politics of place identity in peri-urban environments. What role for productive farming landscapes? A case study of Wollondilly Shire, NSW, Australia., Univeristy of Technology Sydney

Rüter S, Vos CC, van Eupen M, Rühmkorf H (2014) Transboundary ecological networks as an adaptation strategy to climate change: the example of the Dutch-German border. Basic Appl Ecol 15(8):639-650

Snoeijer MH (2014) Landscape changes and the effect of decollectivisation in the municipalities Răteşti and Stăncuţa (South-Eastern Romania) during the post-communist period (1989-now). University of Groningen

Stobbelaar DJ, Pedroli B (2011) Perspectives on landscape identity: a conceptual challenge. Landsc Res 36(3):321-339

Stürck J, Verburg PH (2016) Multifunctionality at what scale? A landscape multifunctionality assessment for the European Union under conditions of land use change. Landscape Ecol 32:1-20

Swaffield S, Primdahl J (2010) Globalisation and local agricultural landscapes: patterns of change, policy dilemmas and research questions. In: Primdahl J. andSwaffield S. (eds), Globalisation and Agricultural Landscapes - Change Patterns and Policy Trends in Developed Countries. Cambridge University Press, Cambridge, pp. 245-270

Termorshuizen JW, Opdam P (2009) Landscape services as a bridge between landscape ecology and sustainable development. Landscape Ecol 24(8):1037-1052

Terres JM, Scacchiafichi LN, Wania A, Ambar M, Anguiano E, Buckwell A, Coppola A, Gocht A, Källström HN, Pointereau P (2015) Farmland abandonment in Europe: identification of drivers and indicators, and development of a composite indicator of risk. Land Use Policy 49:20-34

Tress B, Tress G (2001) Capitalising on multiplicity: a transdisciplinary systems approach to landscape research. Landsc Urban Plan 57(3):143-157

Vallés-Planells M, Galiana F, Van Eetvelde V (2014) A classification of landscape services to support local landscape planning. Ecol Soc. https://doi.org/10.5751/ES-06251190144

Van Berkel DB, Verburg PH (2014) Spatial quantification and valuation of cultural ecosystem services in an agricultural landscape. Ecol Ind 37:163-174

Van den Brink A, Van der Valk A, Van Dijk T (2006) Planning and the challenges of the metropolitan landscape: innovation in the Netherlands. Int Plann Stud 11(3-4):147-165

Van der Sluis T, Bloemmen M, Bouwma I (2004) European corridors: strategies for corridor development for target species. [accessed on 01.03.17 on URL http://content. alterra.wur.nl/webdocs/internet/corporate/prodpubl/ boekjesbrochures/ecnc_compleet.pdf]. ALTERRA, ECNC, Tilburg/Wageningen, The Netherlands, pp. 33

Van der Sluis T, Kizos T, Pedroli B (2014a) Landscape change in Mediterranean farmlands: impacts of land abandonment on cultivation terraces in Portofino (Italy) and Lesvos (Greece). J Landsc Ecol 7(1):23-44

Van der Sluis T, Kristensen SBP, Frederiksen P, Cosor G, Vădineanu A, Pavlis E, Terkenli TS, Gaube V, Vesterager JP (2014b) Landscape change processes in case study areas 
(WP2). Deliverable 2.3 VOLANTE. http://volante-project. eu/images/stories/DELIVERABLES/VOLANTE_D2.3_ Landscape_change_processes_in_case_study_areas.pdf]. VOLANTE Project Reports, ALTERRA, Wageningen, pp 87. Accessed 1 Nov 2018

Van Doorn AM, Bakker MM (2007) The destination of arable land in a marginal agricultural landscape in South Portugal: an exploration of land use change determinants. Landscape Ecol 22(7):1073-1087

Van Vliet J, de Groot HLF, Rietveld P, Verburg PH (2015) Manifestations and underlying drivers of agricultural land use change in Europe. Landsc Urban Plann 133:24-36

Verhoeve A, De Roo N, Rogge E (2012) How to visualise the invisible: revealing re-use of rural buildings by non-agricultural entrepreneurs in the region of Roeselare-Tielt (Belgium). Land Use Policy 29(2):407-416

Verhoeve A, Dewaelheyns V, Kerselaers E, Rogge E, Gulinck H (2015) Virtual farmland: grasping the occupation of agricultural land by non-agricultural land uses. Land Use Policy 42:547-556
Vesterager JP, Frederiksen P, Kristensen SBP, Vadineanu A, Gaube V, Geamana NA, Pavlis V, Terkenli TS, Bucur MM, Van der Sluis T, Busck AG (2016) Dynamics in national agri-environmental policy implementation under changing EU policy priorities: does one size fit all? Land Use Policy 57:764-776

Vos W, Stortelder A (1992) Vanishing Tuscan Landscapes. Landscape Ecology of a Submediterranean-Montane Area (Solano Basin, Tuscany, Italy). Center for Agricultural Publishing and Documentation (Pudoc), Wageningen, The Netherlands

Walz U (2011) Landscape structure, landscape metrics and biodiversity. Living Rev Landsc Res 5(3):1-35

Wascher DM Landscape Indicator Development: Steps towards a European approach. In: Jongman R. (ed) The new dimensions of the European landscapes; Frontis workshop on the future of the European cultural landscape, Dordrecht 2004. vol 4. Wageningen UR Frontis Series, p. 237-252

Wilson GA (2007) Multifunctional agriculture: a transition theory perspective. $\mathrm{CABI}$ 